\title{
The Drive for a Regional Hub Port for West Africa: General Requirements and Capacity Forecast
}

\author{
George Kobina van Dyck \\ School of Economics and Management, Shanghai Maritime University, Shanghai, China
}

Email address:

kobivandyck@yahoo.com

To cite this article:

George Kobina van Dyck. The Drive for a Regional Hub Port for West Africa: General Requirements and Capacity Forecast. International Journal of Business and Economics Research. Vol. 4, No. 2, 2015, pp. 36-44. doi: 10.11648/j.ijber.20150402.13

\begin{abstract}
Currently there is a drive by a number of West African Ports to attain the status of hub port for the region. This has been driven largely by increasing container throughput in the region in addition to increasing costs for shippers; the latter being attributed to the lack of economies of scale and inefficiencies in ports. This study gathers from literature a consensus on the basic requirements or influential factors of a potential hub location. A survey is carried out to determine the relative importance of hub port requirements according to the major shipping lines operating in the West African region. From the survey, it was established that high port efficiency and performance, stable political environment of the country concerned, and adequate port infrastructure and handling facilities were the three most important requirements/influential factors respectively for a potential West-African hub port, according to the major shipping lines calling at ports in the region. In addition, container throughput levels for West Africa are analysed and a forecast of throughput levels made utilizing a regression model. On average, container throughput will increase at a rate of $10 \%$ per annum in West Africa for the next decade as the economies of the region also continue to grow with a forecasted GDP growth rate of about $11 \%$ per annum. The regression model expands on the relationships between certain economic factors and container throughput levels in West Africa.
\end{abstract}

Keywords: West Africa, Regional Hub Port, Hub Port Requirements, Forecasting, Linear Regression

\section{Introduction}

In the last decade, world trade has been steadily increasing in value (with exception of 2009 due to the world economic crisis) due to increased international trade. In 2012, about 9.2 billion tonnes of goods were loaded in ports world-wide with tanker trade accounting for less than a third of the total and dry cargo responsible for the remaining share [1]. African countries are noted sources for raw materials for many developed countries [2] and their economies are gradually expanding with associated international integration. This has resulted in a significant increase in demand for international transport services to and from the region. In the recent past, few African ports were capable of handling the latest generation of ships and were not equiped to handle the dynamic shipping patterns that were underway. Some African ports lacked container gantry cranes and were more reliant on ships' gear for loading and unloading [3]. Handling efficiency was low evidenced by usually between an average of 10 and 20 container moves per crane hour, compared with between 25 and 30 in leading world ports. This situation was far worse when ships' gear was used with only 7 to 10 moves per hour. Also, the average time spent in a terminal was 6 to 15 days in Africa, whereas the accepted international standard is no more than 7 days [4].

As a result of increased international trade and increased demand for shipping services, in addition to the increased presence of global shipping lines and terminal operators, many coastal African countries are investing in the mordernization and development of their ports into regional hubs in order to provide transhipmnet services for cargo destined for countries in their region. Governments and port authorities have realised the benefits that transshipment services can bring, not only in the form of increased revenue and investment, but also the social advantages of employment and development. 


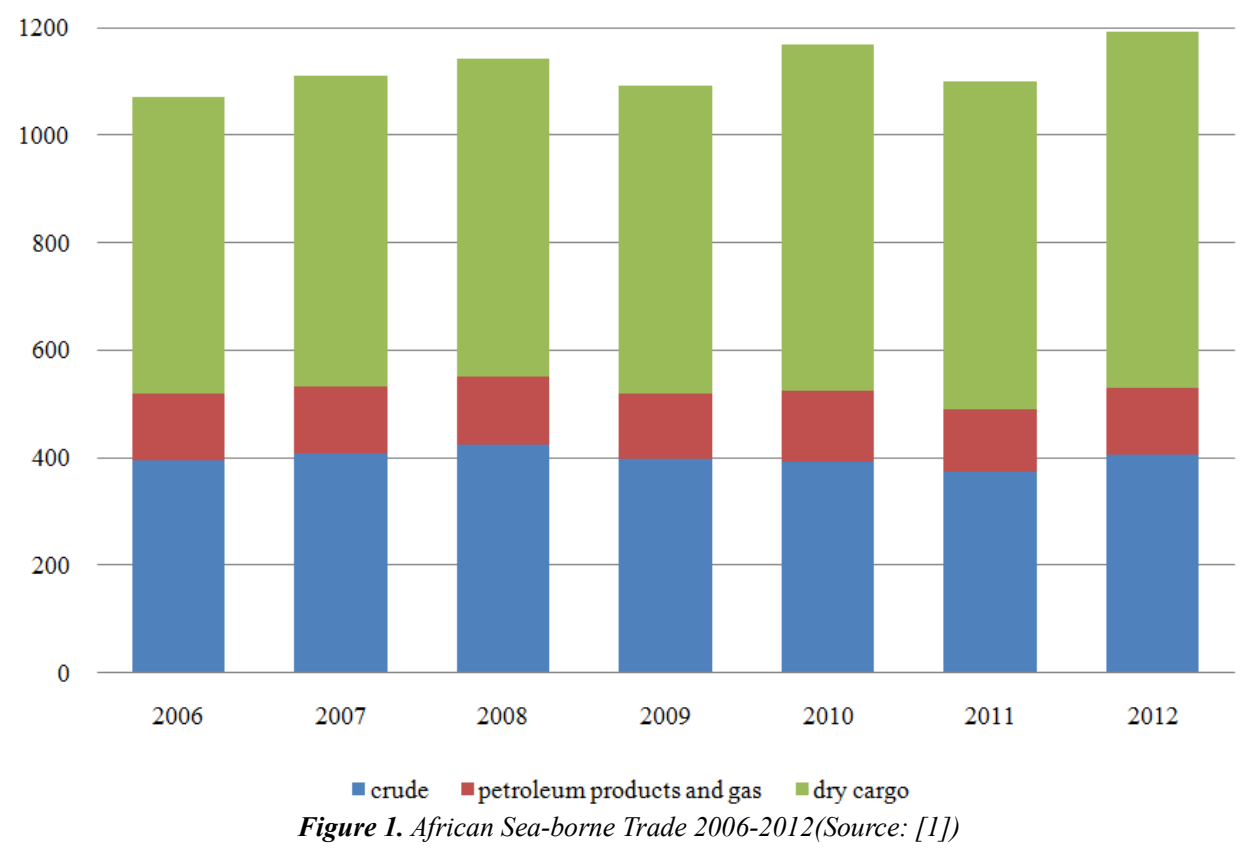

\section{West-African Port Landscape}

In West Africa (WA), maritime trade and in particular container trade is developing at a very fast rate. In the last decade, container throughput levels have increased by an average of $20 \%$ per annum with population and Gross Domestic Product (GDP) growing at an average yearly rate of $3 \%$ and $21 \%$ respectively. Many West African ports have initiated reforms within the last two decades in order to increase capacity and improve operational efficiency. Ports in WA are currently showing signs of more concentration and the development of hub and spoke networks in line with global shipping trends. This has been attributed to PrivatePublic partnerships (PPP) in the form of terminal concessions and has become the driving force in inter-port competition in West Africa. Notably in WA, inter-port competition is highest amongst ports that already play a regional role. They include ports in Ghana, Togo, Ivory Coast and Benin, who provide transit services for landlocked countries in West Africa. Competition between shipping lines and terminal operators is also increasing in bids for port concessions as many ports move away from the service port model to a landlord port management model.

Today, modern equipment at ports like container terminals with gantry cranes is becoming a widespread phenomenon [5]. Currently, there is an intense drive by a number of littoral West-African states to attain the regional hub port status, and all the benefits associated with it. Their efforts have been directed at allowing shipping lines to take advantage of scale economies (as is prevalent in shipping today) as container throughput for WA continues to rise and reach significant levels. The development agenda is directed at improving infrastructure, increasing efficiency and productivity, and providing efficient inland access to hinterlands. All these developmental plans are directed at providing the right setting for the establishment of a regional hub and spoke network by individual competing countries.

The aim of this paper therefore, is to determine the general requirements or influential factors for the establishment of a hub port in West Africa that competing ports must consider during this planning and transition stage. The hub port concept is facilitated by containerization which facilitates faster transfer of goods between transport assets and modes. Therefore, to aid in strategic port planning in addition to medium-term facility expansion and development, this paper will also attempt to forecast container throughput volumes for WA. The forecast is useful for governments, port authorities, policy makers and port development partners in WA as each competing West African port builds infrastructure, expands capacity and seeks to improve productivity in order to obtain the "hub port" status.

\section{The Hub Port Concept and the Requirements for a hub in West Africa}

The hub port concept is not new to the world of shipping but has received much attention within the last half century. This is primarily due to rapidly ascending levels of international trade, with associated expolitation of economies of scale to reduce costs. This has been acheived by utilizing larger vessels for carriage of goods to fewer ports of calls. Reference [6] states that "the hub and spoke concept is intended to maximize utilization of large containerships while providing market coverage to a maximum number of ports. This is accomplished via a network of regional and subregional hubs with onward service to outlying locations".

In the past, the largest container port of a specific region or the port that handled the most cargo in a region became the hub port. Currently, this is not always the case as some hubs that exist today may have no local cargo to offer at all. The development of hub ports is also correlated to the increase in 
port container traffic and the resultant increases in demand for additional container capacity. Transshipment has grown more than three-fold in the last decade making it the fastest growing segment in the container port sector [7]. There are many differing opinions in literature on the different requirements, conditions or influential factors of a hub port.

Reference [8] points out factors that influence the quality of a hub port. They include Port infrastructure (number of berths and yard area size), port services (rate of loading and discharge, information availability, pick-up and delivery services), carriers service in port (berth space availability, freight rate and participation in inland transport), hinterland accessibility (intermodal operating time and cost, customs clearance procedure and cargo tracing services) and lastly port information structure (port community system, information interchange with customs, information interchange between intermodal organizations).

Reference [9] outlines influential factors of hub port choice in East Asia based on literature and expert opinion. Shipping lines in turn ranked each of the factors in order of importance according to a simple Likert scale. The first four factors ranging from most important to less important were cargo source of hinterland, efficiency of handling facilities, saving in operating cost and frequency of trunk and feeder routes. The two factors that were rated the least influential were political considerations and the type of port authority.

Reference [10] bases it on the following important points.

Table 1. Important hub port requirements (Source: [10])

\begin{tabular}{ll}
\hline Requirement & Description \\
\hline Location & $\begin{array}{l}\text { A hub port must be located along the main shipping trade routes and surrounded by industrialized regions. In addition, it must } \\
\text { have deep berths in order to accommodate large container vessels. } \\
\text { Hub ports are characterized by the utilization of modern equipment, simplified procedures with minimum documentation and } \\
\text { higher level of computerization. Also, their system of operation must be efficient enough to reduce the turnaround times for } \\
\text { vessels. }\end{array}$ \\
Capability & $\begin{array}{l}\text { The port seeking to become a hub port must have well established safety and security protocols in place. } \\
\text { Environment }\end{array}$ \\
$\begin{array}{l}\text { Commercial } \\
\text { environment }\end{array}$ & $\begin{array}{l}\text { A hub port must provide the requisite support to vessels that call in terms of telecommunication services, water supplies, ship } \\
\text { repairs, waste disposal and medical services. } \\
\text { Ancillary services }\end{array}$ \\
Agevernment agencies and other important commercial services must be available around the clock to handle shipping-related \\
tasks. Such agencies for instance, include, port regulatory authorities, maritime administrations, customs, immigration, health, \\
agriculture and vet, banking, insurance and surveyors.
\end{tabular}

Table 2. Ranking of determinants for hub port (Source: [11])

\begin{tabular}{ll}
\hline Determinants & Shipping lines Rank \\
\hline High port efficiency & $1^{\text {st }}$ \\
Adequate port infrastructure & $2^{\text {nd }}$ \\
Wide range of port facilities & $3^{\text {rd }}$ \\
Low port charges & $4^{\text {th }}$ \\
Adequate info-structure & $5^{\text {th }}$ \\
Connectivity to other ports & $6^{\text {th }}$ \\
Location & $7^{\text {th }}$ \\
\hline
\end{tabular}

Reference [11] ranks the determinants of hub port choice according to 25 major shipping lines operating in Singapore. Port efficiency, port capacity and facilities are the predominant factors that shipping lines ranked as the three most important. Interestingly enough, location was ranked the least important. Below is a table showing the results.

Reference [4] also outlines basic transshipment requirements of a hub port. In this particular report, attention is drawn to the political and port governance role in the establishment of a hub port. Also differing in this report was the addition of limited corruptive practices as a hub port requirement.

Summarily, from the literature discussed above, hub port determinants or influential factors can be generally divided into four (4) broad categories that range from physical infrastructure to management structure and policies. The different categories that emerge below represent a consensus of requirements across all the literature reviewed by the author.

A.Port and hinterland infrastructure determinants Requisite port location close to major shipping routes, adequate port infrastructure and handling facilities (sufficient port land area availability, requisite number of berths and adequate yard size, adequate storage facilities, sufficient and appropriate equipment, etc) appropriate depth of approach channel and port, modern multimodal transport infrastructure.

B.Port service and info-structure determinants - High port efficiency, competitive costs of port services and tariffs, minimal waiting time for berths by ships, safe and secure port access and area, information availability and visibility

C. Trade facilitation determinants - Quality customs, immigration and health services, considerable volumes of import and export container throughput, zones for distribution, consolidation, value-added and re-export services, active port community system (ship and port service providers, etc), information interchange between port intermodal organizations, limited corruptive and bureaucratic policies and practices, Limited inland delays and checkpoints

D.Political and port management determinants - Port management type, good port labour relations, stable political system and appropriate maritime policies of government 


\section{Hub Port Requirements Survey for Major Shipping Lines Operating in West Africa}

Based on the categories of hub port requirements derived above, a questionnaire survey was developed to determine the relative importance of the factors identified in the West African region. The questionnaire was distributed to major shipping lines calling at ports in West Africa. Questionnaires were distributed to 21 major shipping lines and 17 valid responses were received. The questionnaire simply required the respondents to rank the influential factors based on a simple Likert Scale ranging from $1-5 ; 1$ - indicating the least important factor to 5 - indicating most important. A sample of the questionnaire can be found in the appendix. The results of the survey are presented in this section.

Table 3. Shipping Lines ranking of hub port requirements according to categories

\begin{tabular}{|c|c|c|c|}
\hline \multicolumn{4}{|c|}{ Category A - Port and Hinterland infrastructure determinants } \\
\hline Rank & Mean Score & Code & Requirements \\
\hline 1 & 4.53 & A2 & Adequate port infrastructure and handling facilities \\
\hline 2 & 4.06 & A1 & Requisite location of port \\
\hline 3 & 3.94 & A3 & Appropriate depth of approach channel and port \\
\hline 4 & 2.00 & A4 & Appropriate multimodal transport infrastructure \\
\hline \multicolumn{4}{|c|}{ Category B - Port service and information-structure determinants } \\
\hline 1 & 4.82 & B1 & High port efficiency and performance \\
\hline 2 & 4.53 & B2 & Competitive cost of port services and tariffs \\
\hline 3 & 4.47 & B3 & Minimal berth waiting time \\
\hline 4 & 4.41 & B4 & Safe and secure port area \\
\hline 5 & 4.35 & B5 & Information availability and visibility \\
\hline \multicolumn{4}{|c|}{ Category C - Trade facilitation determinants } \\
\hline Rank & Mean Score & Code & Requirements \\
\hline 2 & 4.00 & $\mathrm{C} 7$ & Limited corruptive and bureaucratic practices \\
\hline 3 & 3.88 & $\mathrm{C} 4$ & Active port community system \\
\hline 4 & 3.53 & $\mathrm{C} 2$ & Considerable volumes of import and export container throughput \\
\hline 5 & 2.88 & $\mathrm{C} 1$ & Quality customs, immigration and health services \\
\hline 6 & 2.76 & $\mathrm{C} 3$ & Zones for distribution, consolidation, value-added and re-export \\
\hline 7 & 2.71 & C6 & Limited inland delays and checkpoints \\
\hline \multicolumn{4}{|c|}{ Category D - Political and port management determinants } \\
\hline Rank & Mean Score & Code & Requirements \\
\hline 1 & 4.65 & D3 & Stable political system of country \\
\hline 2 & 4.47 & D4 & Appropriate maritime policies of government \\
\hline 3 & 4.41 & D2 & Good port labour relations \\
\hline 4 & 3.29 & D1 & Port management model \\
\hline
\end{tabular}

Table 4. Complete ranking of all hub port requirements by shipping lines

\begin{tabular}{|c|c|c|c|}
\hline Rank & Mean Score & Code & Requirements \\
\hline 1 & 4.82 & B1 & High port efficiency and performance \\
\hline 2 & 4.65 & D3 & Stable political system of country \\
\hline 3 & 4.53 & $\mathrm{~A} 2$ & Adequate port infrastructure and handling facilities \\
\hline 3 & 4.53 & B2 & Competitive cost of port services and tariffs \\
\hline 4 & 4.47 & B3 & Minimal berth waiting time \\
\hline 4 & 4.47 & D4 & Appropriate maritime policies of government \\
\hline 5 & 4.41 & B4 & Safe and secure port area \\
\hline 6 & 4.35 & B5 & Information availability and visibility \\
\hline 7 & 4.12 & $\mathrm{C} 5$ & Access to information \\
\hline 8 & 4.06 & A1 & Requisite location of port \\
\hline 9 & 4.00 & $\mathrm{C} 7$ & Limited corruptive and bureaucratic practices \\
\hline 10 & 3.94 & A3 & Appropriate depth of approach channel and port \\
\hline 11 & 3.88 & $\mathrm{C} 4$ & Active port community system \\
\hline 12 & 3.53 & $\mathrm{C} 2$ & Considerable volumes of import and export container throughput \\
\hline 15 & 2.76 & $\mathrm{C} 3$ & Zones for distribution, consolidation, value-added and re-export \\
\hline 16 & 2.71 & C6 & Limited inland delays and checkpoints \\
\hline 17 & 2.00 & A4 & Appropriate multimodal transport infrastructure \\
\hline
\end{tabular}


The score of each influential factor under each category is calculated on the basis of seventeen (17) valid responses out of twenty-one (21) of major shipping lines calling at West African ports. Each factor is ranked on the basis of the mean scores derived from the Likert scale. The larger the score out of five, the more important the requirement is to the shipping lines. Table 4 is a combined table of the total ranking of the hub port requirements across all categories. The differences in average scores are quite minimal indicating that the factors are all quite similarly important to the respondents. From the first to the ninth ranked requirement, the mean score was not lower than 4 denoting that those requirements ranged from very important to most important to all shipping lines. High port efficiency and performance in addition to stable political system of the country concerned are ranked as the two most important factors/requirements. The factors of less importance to the shipping lines are linked to trade facilitation requirements and multimodal transport infrastructure. As these activities are not directly linked to the port service at the ship/port interface, it stands to give reason to the minimal concern with those requirements by the shipping lines.

\section{Capacity Forecast for a Potential West-African Hub Port}

Prediction of throughput volumes has significant influence on port development strategy, and the ability to provide quality and efficient services. In predicting throughput volumes in international trade, several qualitative and quantitative forecasting models and techniques have been proposed and developed by international scholars. Qualitative forecasts have however been noted to lack objectivity [12]. Predictive methods (both qualitative and quantitative) have varying characteristics, and as such may differ in accuracy of prediction, complexity in technique and applicability. Some methods are suitable for long term forecasting and others for short term forecasting.

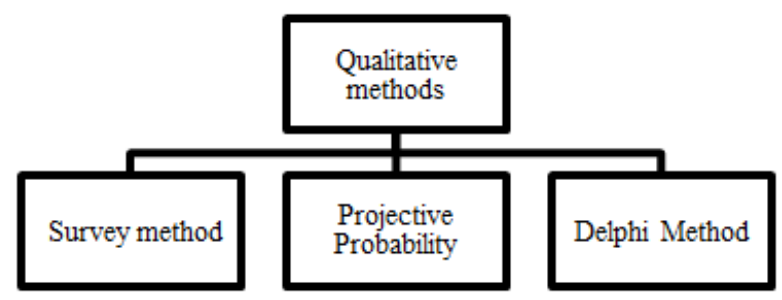

Figure 2. Common Qualitative Techniques (Source: [12])

\subsection{Linear Regression Model}

One of the most common quantitative prediction techniques is the linear regression model and it has been widely used in port throughput studies to both identify determinants of throughput and to execute forecasting. Linear regression seeks to identify and measure casual relationships between variables [13]. Reference [14] and [15] used linear regression to illustrate the causal relationship between the determinants of cargo throughput and port performance. Similarly, [16] predicted the level of cargo growth by regression analysis in Hong Kong. Factors affecting cargo throughput were qualitatively evaluated, entered into the forecast model and used to project the cargo throughput of the port. In addition, in forecasting volumes of import containers in Taiwan, a modified regression model was developed to ensure better forecast accuracy [17]. In this case, after comparing the modified regression model with the classical regression model, the study found that the modified model exhibited higher prediction accuracy.

Other predictive models utilized in cargo and container throughput studies are worth mentioning. Some of these models have also been used, and sometimes modified to increase prediction accuracy as in the case of [17] above.

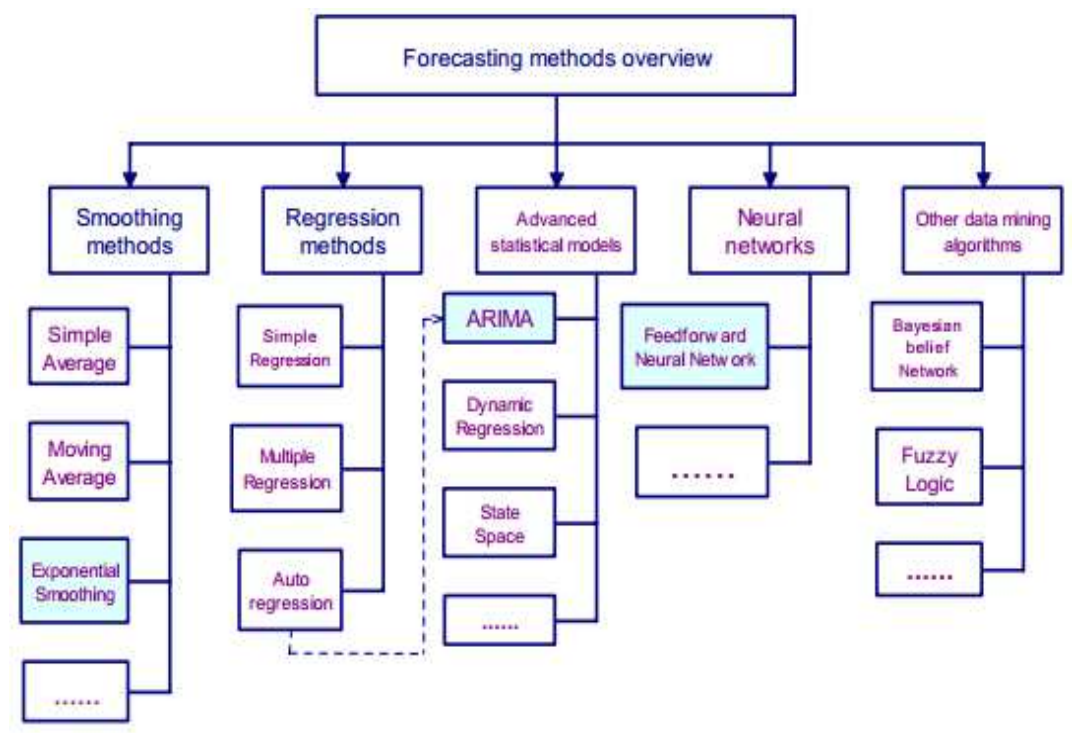

Figure 3. Common Quantitative forecasting methods (Source: [24]) 
Some authors [18] proposed a double forecasting model based on conditional expectation through probability distribution of port cargo throughput. Others [19] have employed the grey model in forecasting transportation demand. A modified Grey theory using Fourier series FRMGM $(1,1)$ for improving forecasting accuracy of cargo forecasts at Kaohsiung ports from 2013-2015 has also been utilized [20]. Some models have been studied and their accuracy compared to select the optimum results. Combination forecasts have also been utilized in port throughput studies. Reference [21] created an optimal predictive model for container throughputs at ports using genetic programming, decomposition approach (x-11), and Seasonal Auto-Regressive Integrated Moving Average (SARIMA). The results showed that genetic programming was the best method for predicting the container throughput. Additionally, [22] propose a new forecasting model able to take advantage of domain knowledge and avoid biases and inconsistencies inherent in subjective judgments. The method was compared to the frequently used ARIMAX model and the results proved the new model out-performed the ARIMAX model. Reference [23] also compared the performance of ARIMA model, Grey Model, and their joint Fourier modified model aimed at obtaining an efficient model to forecast cargo throughput. The authors found that the accuracy of the conventional models was significantly boosted with the Fourier modification. Additionally, [12] aimed to improve the accuracy of forecasting cargo throughput by applying the combined model composed of grey-forecast model and Logistic-growth-curve model. The validity of the combined model was tested by applying it to current port data thereby confirming the combined model can obtain relatively higher forecast accuracy than the conventional ones.

Complex models however do not always produce more accurate results. This notion is supported by [13] who identified that container volumes were best forecast using classical time-series decomposition and that the application of more complex models did not necessarily produce more accurate results. In this paper, forecasting container throughput for the West African sub-region is executed using a classical time-series regression model. This method will also detail the relationship between certain economic factors and container throughput volumes for the region.

\subsection{Factors Affecting Container Throughput in West Africa}

The factors that affect container throughput in WA can be grouped into two categories - macroeconomic indicators and other factors. Macroeconomic indicators include gross Domestic Product (GDP), population growth, Foreign Direct Investment (FDI), and level of imports and Exports. The other factor to be discussed includes the signing of the EPA agreement.

\subsubsection{Macroeconomic Indicators}

Growth in container throughput is ultimately driven by economic growth in West Africa. In this study, macroeconomic variables are the primary determinants used in forecasting container throughput in WA. The underlying assumption with regards to the forecast is that the underlying relationship between the growth in container throughput and economic growth of the West African region will remain structurally unchanged. Therefore, expectations of future economic growth are also incorporated into the model to derive the predicted container throughput for the region. A regression equation is used to predict the linear relationship between the macroeconomic variable(s) and container throughput levels.

\subsubsection{Economic Partnership Agreement and West Africa}

The signing of the EPA cannot be incorporated into the model as there is no historical data available. However, this factor will be qualitatively discussed and treated as an external shock that impacts the regression results as in [16].

The EPA is a trade and development agreement negotiated between the EU and the African, Caribbean and Pacific (ACP) regions engaged in regional economic integration process. The agreement between the EU and ACP regions are primarily aimed at promoting trade between the two [25]. The intial aim of the EPAs is to provide increased market access directed at enhancing trade volumes between the two participating groups.

For the West African region, the agreement currently covers goods and development-related cooperation. Rendezvous clauses were provided for further negotiations on service and rules chapters. Negotiations were closed in February 2014, the text was initiated on 30 June and 10 July 2014; ECOWAS (Economic Community for West African States) heads of state endorsed the EPA for signature. The agreement is to be submitted to parties for ratification [25]. The first interim agreements in West Africa were signed by Ivory Coast and Ghana. According to [26], average yearly trade volumes between EU and Ivory Coast and Ghana have increased considerably in both directions since the signing of the interim agreements. Therefore, we can assume that the EPA's signed should have a positive linear relationship with container throughput as trade volumes increase.

\subsection{Forecast Data}

The cargo throughput data for WA has been collated from the websites of the various West African port authorities and the World Bank from 2002-2012. This data represents the total number of containers loaded and unloaded at West African ports and is representative of the total container trade for the West African sub-region for the period 20022012. The forecasts based on the different models are derived from this throughput data.

From the year 2002-2012, a total of about 25 million TEU has been loaded and discharged through ports in WA. Container throughput has increased at an average of $20 \%$ per annum with GDP growing at a similar average rate of $21 \%$ per annum. 
Table 5. Container throughput for WA (Source: [27] and [28])

\begin{tabular}{lll}
\hline Year & Container Throughput (TEU)* & GDP $(\$)$ \\
\hline 2002 & $849,938.00$ & $101,435,298,834.14$ \\
2003 & $1,548,005.00$ & $119,408,765,034.77$ \\
2004 & $1,570,928.00$ & $146,583,146,406.96$ \\
2005 & $1,154,866.00$ & $175,972,920,798.62$ \\
2006 & $1,326,118.00$ & $222,742,274,834.48$ \\
2007 & $2,443,824.00$ & $258,546,818,667.72$ \\
2008 & $2,956,296.00$ & $317,151,562,048.59$ \\
2009 & $3,056,494.00$ & $275,436,374,809.22$ \\
2010 & $3,144,526.02$ & $483,229,648,059.41$ \\
2011 & $3,587,489.39$ & $541,598,327,968.67$ \\
2012 & $3,704,989.65$ & $597,411,463,254.65$ \\
\hline
\end{tabular}

${ }^{*}$ TEU - Twenty-foot equivalent units

\subsection{Forecast Model and Analysis}

In determining the economic indicators to be used in the regression model, several indicators were tested to check their level of correlation. Most notably used in previous research include population growth, Gross Domestic Product (GDP), Foreign Direct Investment (FDI) inflows and the level of imports and exports. The economic data used in the regression model is based on the assumption that economic drivers are the key determinants of container throughput for the West African sub-region. A correlation matrix was run to initially determine the level of correlation between the macroeconomic variables themselves and also between the variables and container throughput. It was determined that there was a very high correlation between GDP and container throughput from the regression analysis and it was used in the regression model to predict future container throughput volumes for WA. The GDP figures were sourced from World Bank Statistics and covers the period 2002 to 2012. The model was run using Microsoft excel. The equations predicted in the regression model take the following form:

$$
y=\alpha+\beta x
$$

The accuracy of the regression model was first checked by looking at the $\mathrm{R}$ square and adjusted $\mathrm{R}$ square figures from the output. The $\mathrm{R}$ square value was 0.81 which indicates that 81 percent (\%) of the variance of the output variable (container throughput) can be explained by the variance of the input variable (GDP). The adjusted $\mathrm{R}$ square, which is a more conservative form of the $\mathrm{R}$ square, was 0.79 and indicates the model modestly fits the data. Also, the "significance F' figure for the model was derived as 0.00015 and this indicates that the output of the model is not random but is significant ( $F$ was less than 0.05). The container throughput and GDP is set respectively as, $y$ and $x$. In order to predict the future container volumes using the regression equation, future GDP figures had to be forecasted first and applied in the equation and variable ' $x$ ' above. The final regression equation derived was:

$$
y=708165.14+0.0000054 x
$$

The final results of the forecast can be seen in table 6 . Container throughput will increase to about 12 million TEU in 2022 from about 4 million in 2012, an increase by approximately $220 \%$. On average, container throughput will increase at a rate of $10 \%$ per annum in WA as the economies of the region continue to grow with a forecasted GDP growth of about $11 \%$ per annum for the next 10 years.

Table 6. Forecasted throughput for WA

\begin{tabular}{ll}
\hline Year & Forecasted Throughput (TEU's) \\
\hline 2013 & $4,901,344.79$ \\
2014 & $5,674,696.88$ \\
2015 & $6,448,048.98$ \\
2016 & $7,221,401.07$ \\
2017 & $7,994,753.17$ \\
2018 & $8,768,105.26$ \\
2019 & $9,541,457.36$ \\
2020 & $10,314,809.45$ \\
2021 & $11,088,161.55$ \\
2022 & $11,861,513.64$ \\
\hline
\end{tabular}

\section{Conclusions}

At present, West African ports are fiercely competing to obtain regional hub port status to facilitate the transshipment of containers across the region in cognizance of the derived benefits. This competition which is at its early stages has seen significant planning and investment in port facilities. For such strategic investment in such huge projects across the region, it is important to understand the requirements of the shipping lines these potential hubs will serve and the dynamics of change with regards to demand for containers in the entire region. From the survey, it was established that high port efficiency and performance, stable political environment of the country concerned, and adequate port infrastructure and handling facilities were the three most important requirements/influential factors respectively for a potential West-African hub port according to the major shipping lines in the region. Of less importance to the shipping lines were zones for distribution, consolidation, value-added and re-export, limited inland delays and checkpoints, and appropriate multimodal transport infrastructure. The requisite location of the potential hub port was ranked $8^{\text {th }}$ overall but was still relatively very important to shipping lines according to the mean score it derived.

In addition, a ten-year forecast was derived from the regression forecasting model used in this paper. The forecast revealed that container throughput for WA will continue to grow in the coming years at an average rate of $10 \%$ per annum, as GDP of the region also grows at a similar rate. This forecast of container throughput draws a vivid picture of quantity/capacity expectations of ports that are vying to serve as the transshipment centre for the region. By 2018, container throughput for WA would reach almost 9 million TEU and by 2022, the region could see an additional 2 million TEU 
increase in throughput. Therefore, port planning and development strategies by port authorities and governments in WA have to take into account the growing numbers of containers meant for the region in addition to domestic demand for non-containerized goods. Additionally, it was established that the signing of the EPA would increase future throughput levels of containers as the agreement is meant to increase trade between WA and EU. However, empirical research is needed to quantify the level of increase in container throughput that can be attributed to the EPA. It should also be noted that predicting future throughput levels is just a first step in planning and development, as hub ports are not only measured by their capacity as the survey vividly displays. Future research may be directed at determining the relative efficiencies of the different competing ports in WA as part of the greater drive for a hub port in the region.

\section{Appendix}

\section{Questionnaire for Shipping Lines}

Name of shipping line:

Hub port requirements for West Africa - The hub port requirements below are in 4 categories. A Likert scale has been applied to the requirements listed under each category. Please tick the requirements according to their importance to your operations.

$1=$ least important, $2=$ less important, $3=$ important, $4=$ very important, $5=$ most important

Category $\boldsymbol{A}$ - Port and Hinterland infrastructure determinants

\begin{tabular}{lllll}
\hline Requirements & \multicolumn{3}{c}{ Scale } & \\
\cline { 2 - 4 } & $\mathbf{1}$ & $\mathbf{2}$ & $\mathbf{3}$ & $\mathbf{4}$ \\
\hline Requisite location of port \\
Adequate port infrastructure and handling facilities* \\
Appropriate depth of approach channel and port \\
Appropriate multimodal transport infrastructure**
\end{tabular}

* includes adequate land area, requisite number of berths, adequate storage facilities, sufficient and appropriate equipment etc

** Inland roads, rail and water transport facilities

Category B - Port service and info-structure determinants

\begin{tabular}{lllll}
\hline Requirements & Scale & & \\
\cline { 2 - 4 } & $\mathbf{1}$ & $\mathbf{2}$ & $\mathbf{3}$ & $\mathbf{4}$ \\
\hline High port efficiency and performance & & $\mathbf{5}$ \\
Competitive cost of port services and tariffs & & & \\
Minimal berth waiting time & & & \\
Safe and secure port area & & & \\
Information availability and visibility & & \\
\hline
\end{tabular}

Category C - Trade facilitation determinants

\begin{tabular}{|c|c|c|c|c|c|}
\hline \multirow{2}{*}{ Requirements } & \multicolumn{5}{|c|}{ Scale } \\
\hline & 1 & 2 & 3 & 4 & 5 \\
\hline \multicolumn{6}{|l|}{ Quality customs, immigration and health services } \\
\hline \multicolumn{6}{|c|}{ Considerable volumes of import and export container throughput } \\
\hline \multicolumn{6}{|c|}{ Zones for distribution, consolidation, value added and re-export } \\
\hline \multicolumn{6}{|c|}{ Active port community system (ship and port service providers, etc) } \\
\hline \multicolumn{6}{|l|}{ Access to information } \\
\hline \multicolumn{6}{|l|}{ Limited inland delays and checkpoints } \\
\hline Limited corruptive and bureaucratic practices & & & & & \\
\hline
\end{tabular}

Category D - Political and port management determinants

\begin{tabular}{lllll}
\hline Requirements & Scale & & \\
\cline { 2 - 4 } & $\mathbf{1}$ & $\mathbf{2}$ & $\mathbf{3}$ & $\mathbf{4}$ \\
\hline Port Management Model (Service port, landlord, etc) & & & & \\
Good port labour relations & & & \\
Stable political system of country & & & \\
Appropriate maritime policies of government & & & \\
\hline
\end{tabular}




\section{References}

[1] UNCTAD/RMT, "Review of Maritime Transport," UNCTAD: United Nations Publication, Geneva, 2013.

[2] L. Trujillo, M. M. González and J. L. Jiménez, "An overview of the reform process of African ports," Utilities Policy 25, pp. 12-22, 2013.

[3] V. Foster and C. Briceño-Garmendia, " Ports and Shipping: Landlords Needed. Africa's infrastructure: A time for Transformation. The International Bank for Reconstruction and Development," The World Bank, 2010.

[4] AFDB, "Gowing forward: Developing Regional Hubs in Africa," 8 October 2010. [Online]. Available: http://www.afdb.org/fileadmin/uploads/afdb/Documents/Publi cations/African\%20Development\%20Report\%202010_CH\%2 06.pdf.

[5] J. Debrie, "The West African port system: global integration and regional particularities," 13 July 2012. [Online]. Available: http://echogeo.revues.org/13070; DOI:10.4000/echogeo.13070.

[6] World Bank, "World Bank Port Reform Toolkit: The Evolution of Ports in a Competitve world," 2007. [Online]. Available:

http://www.ppiaf.org/sites/ppiaf.org/files/documents/toolkits/P ortoolkit/Toolkit/pdf/modules/02_TOOLKIT_Module2.pdf.

[7] T. Notteboom, J. Wang, D. Olivier, B. Slack, Ports, cities and global supply chains, USA and England: Ashgate, 2007.

[8] K. Cullinane and T.-W. Lee, World Shipping and Port Development, England: Palgrave Macmillan, 2005.

[9] H.H. Tai and C.C. Hwang, "Analysis of hub port choice for container trunk lines in East Asia," Journal of the Eastern Asia Society for Transportation Studies, pp. Vol. 6 pp. 907-919, 2005.

[10] M. Goh, "Southeast Asian regional port development," Institute of southeast Asian Studies, Singapore, 2003.

[11] L. Low and D. Johnston, "Singapore Inc.," Eastern Universities Press, Singapore, 2003.

[12] C. Zhang, L. Huang and Z. Zhao, "Research on combination forecast of port cargo throughput based on time series and causality analysis," Journal of Industrial Engineering and Management, 2013.

[13] W.Y. Peng and C.W. Chu, "A comparison of univariate methods for forecasting container throughput volumes," Mathematical and Computer Modelling , pp. Vol. 50 10451057, 2009.

[14] J. Tongzon, "Determinants of Port Performance and Efficiency," Transport Research A, pp. 29(3), 245-352., 1995.

[15] J. Tongzon and $\mathrm{H}$. Wu, "Port privatization, efficiency and competitiveness: Some empirical evidence from container ports (terminals)," Transportation Research Part A , pp. 39 (2005) $405-424,2005$.
[16] W. Seabrooke, E. Hui and W. A. W. G. Lam, "Forecasting cargo growth and regional role of Port of Hong Kong," Cities, pp. Vol. 20, No. 1, pp. 51-64, 2003.

[17] C.C. Chou, C.W. Chu and G.S. Liang, "A modified regression model for forecasting the volumes of Taiwan's import containers," Mathematical and Computer Modelling, pp. Vol. 47, pp. 787-807, 2008.

[18] L. Sun, "Research on a double forecasting Model for port cargo throughput," World Journal of Modelling and Simulation, pp. Vol. 6, No. 1, pp. 57-62, 2010.

[19] W. Huang, S. Wu, P. Cheng and Z. Yu, "Application of grey theory to the transport demand forecast from the viewpoint of life cycle-example for the container port in Taiwan," Journal of Maritime Sciences, pp. Vol. 12 pp. 171-185, 2003.

[20] C.N. Wang and V.T. Phan, "An improvement in the accuracy of Grey forecasting model for cargo throughput in internatioanl commercial ports of Kaohsuing," WSEAS Transactions on Business and Economics, pp. Vol. 11, pp. 322-327, 2014.

[21] S.H. Chen and J.N. Chen, "Forecasting container throughputs at ports using genetic programming," Expert systems with applications, pp. Vol. 37, pp. 2054-2058, 2010.

[22] A. Huang, H. Qiao and S. Wang, "Forecasting container throughputs with domain knowledge," Procedia Computer Science, pp. Vol. 31, pp. 648-655, 2014.

[23] M. Shu, Y. Huang and T. Nguyen, "Forecasting Models for the Cargo Throughput at Hong Kong and Kaohsiung Port," Recent Researches in Applied Economics and Management - Volume I, pp. 189-193, 2013.

[24] X. Wang, K. Smith-Miles and R. Hyndman, "Rule induction for forecasting method selection: meta-learning the characteristics of univariate time series," 29 October 2014. [Online]. Available: http://www.robjhyndman.com/papers/wang3.pdf.

[25] European Commission, "Economic Partnerships," 30 January $2015 . \quad$ [Online]. Available: http://ec.europa.eu/trade/policy/countries-andregions/development/economic-partnerships/.

[26] G. Sommer, "The Economic Partnership Agreements Between the EU and ACP Countires: The Impact on Trade Flow Between EU-Ghana and EU-Ivory Coast," Ph.D thesis, The Univeristy of Twente, Twente, 2011.

[27] WorldBank, "Container port traffic (TEU: 20 foot equivalent units)," $2014 . \quad$ [Online]. Available: http://data.worldbank.org/indicator/IS.SHP.GOOD.TU. [Accessed 13 April 2014].

[28] PMAWCA, "Members, statistics," Port Management Association for West and Central Africa, [Online]. Available: http://www.en.agpaoc-pmawca.org/members/. [Accessed 21 January 2014]. 